\title{
Grade-a-thons and Divide-and-Conquer: Effective Assessment at Scale
}

\section{Ms. Brittany Ann Kos, University of Colorado, Boulder}

Brittany Kos is a PhD student at the ATLAS Institute at the University of Colorado Boulder. Her primary work is in undergraduate Computer Science Education and studying student hackathons from a feminist lens.

\section{Dr. Sarah Miller, University of Colorado, Boulder}

Sarah Miller provides vision and leadership for the recruitment, retention, and success of outstanding and diverse students, faculty, and staff to the University of Colorado Boulder's College of Engineering and Applied Science. As Assistant Dean for Inclusive Excellence, she leads the Broadening Opportunity through Leadership and Diversity (BOLD) Center, overseeing efforts to attract and prepare students for the rigors of engineering study and careers, and to improve student performance and graduation rates. Appointed in January 2014, Miller comes to CU-Boulder from the National Science Foundation, where she worked in STEM education as a American Association for the Advancement of Science Fellow.

Sarah believes that every child deserves an excellent education. She has worked in inner-city public schools, both as a teacher and as an administrator, and in the admissions office of Amherst College, where she earned a B.A. in Chemistry. She holds a PhD from Yale University in chemical and environmental engineering, where her doctoral research produced a bio-based water purification system for removing arsenic from developing world water supplies. 


\section{Grade-a-thons and Divide-and-Conquer: Effective Assessment at Scale}

\section{ABSTRACT}

This complete evidence-based practice paper will describe our successful grading and assessment practices of a large freshmen engineering course. In the Fall of 2016 we taught "Introduction to Engineering", a course designed to help students transition from high school to college and learn strategies to help them become successful engineering students. Over 70\% of the students had not yet declared an engineering major but had intentions to transfer to an engineering major the following spring semester. This was a 1-credit hour, online and in-person hybrid class, technologically managed by a Learning Management Software (LMS).

Over 700 students enrolled in the course, and our instructional team consisted of one Instructor, one graduate TA, and two undergraduate TAs. This paper reports evidence-based practice of two assessment methods, Divide-and-Conquer and Grade-a-thons, that we used to successfully evaluate a large-enrollment course with small grading staff. The coursework was divided into two types of assignments: weekly homework and a final report.

The design of the course was based on content that had been previously implemented at this large, midwestern institution, as well as best practices learned from introduction to engineering courses at other institutions. In particular, the final project was based on Ray Landis' work (Landis 2013). The weekly assignments were 1-page essay assignments. We asked students to reflect on the course's assigned in-person activities, reading, and videos and to create a personal plan that would set themselves up to becoming a successful engineering student. To the best of our understanding, this is the largest implementation of "Design Your Successful Engineering Path" that has been able to grade final reports at this scale.

Weekly assignments were assessed with Divide-and-Conquer style grading. Student assignments were divided by last name into three even sections; each TA was responsible for one section and performed a combination of "hand-grading" and "mass-grading". Hand-grading involved looking at each student's assignment, making an assessment based on a rubric, writing comments, and assigning a grade. Mass-grading consisted of giving all students full credit for the assignment. Every week TAs would hand-grade between 80-100 assignments and mass-grade the remaining 130-150 assignments. They would change which students were selected for hand-grading every week, so no student went more than two weeks without being hand-graded. This strategy allowed three TAs to give select students meaningful feedback on their assignments and monitor student progress. The TAs would first complete the hand-grading, to monitor the quality of student work for that assignment. Through this hand-grading assessment, the TAs found that there was a consistent rate of $90-95 \%$ of students turning in completed work that followed all requirements, earning the students full-credit. Due to the overall quality of student submissions, we justified mass-grading: giving the remaining students full-credit would be a reasonable strategy, since an overwhelming majority of submissions would have been assigned full-credit with the hand-grading strategy. 
The second type of assignment that required assessment was a final report. This report was an accumulation of the previous weekly assignments, where students were expected to create a cohesive strategy to becoming a successful student engineer. These reports were 9-11 pages in length, not including appendices. Since this assignment was significantly longer than the weekly assignments and required that every student be hand-graded, we created a "Grade-a-thon" event that enabled us to grade all student reports in two eight-hour sessions. The grade-a-thon augmented practices seen in hackathons and standardized AP grading assessment. We hired an additional 16 Graders for this event, paying each Grader $\$ 100$ for the entire day. The grade-a-thon was hosted on a Saturday from 9-5 in a large conference and workspace on campus. Before the event, the TAs graded four student reports to create a standardized grading practice. At the beginning of the event, we performed a calibration session where the Graders could see these examples and practice grading reports themselves; through the calibration session, we created regulated grading practices for all grading staff. We catered lunch and provided snacks for the grading team as well as organized breaks and activities every two hours. This prevented burn-out and kept all graders engaged in grading. In the end, this format allowed all students to receive individual assessment and feedback, while simultaneously expediting grading time and at a relatively low financial cost to the university.

We developed the Divide-and-Conquer and Grade-a-thon strategies as alternatives to automated assessment or hiring full-time appointment-based TAs. Our experiences with this introduction to engineering course show us that we can achieve effective assessment for a large enrollment course with a small instructional staff.

\section{BACKGROUND}

Teaching and assessing large introductory classes is a challenge many engineering programs face. Increasing student populations paired with a desire for increased efficiency can lead to teaching challenges (Essick 2016). In this paper, we will discuss our successful practices teaching a large freshmen engineering course. In fall of 2016, we taught "Introduction to Engineering", a course designed to help students transition from high school to college and learn strategies to help them become successful students in our College of Engineering. This course is only taught in the Fall semester when students are first admitted to the college. Historically, this course has presented a challenge for our instructors as they are faced with trying to balance a growing class size with effective teaching and assessment strategies. In the Fall of 2016, we taught this course as a 1-credit hour, hybrid online and in-person class, technologically-managed by a Learning Management Software (LMS).

A majority of our students were first-year engineering students. University admissions auto-enrolled all pre-engineering and open option first-year students in this course; however, it was only required for declared Aerospace Majors and was an optional course for all other students. The initial enrollment was 872 students, but after we informed students it was not a required course for many of them, our enrollment dropped to 701 students. We then separated students into three groups: "Pre-Engineers" (60\% of the population), "Aerospace Engineers" ( $17 \%$ of the population), "Other Engineers" (18\% were undeclared and 5\% had a declared major). "Pre-Engineers" are students who applied to the College of Engineering, but due to a 
high volume of applicants to the college and their lower high school scores, they were denied admission to the College of Engineering, but accepted into the College of Arts and Sciences. These students take similar engineering classes as admitted engineering students and re-apply to the College of Engineering in the spring semester. The "Other Engineers" group are students who have been admitted to the College of Engineering and fall into one of two categories: 1) they have declared a non-Aerospace Engineering major, such as Mechanical Engineering or Computer Science; or 2) they are Open Option student and did not declare a major when they applied to the College of Engineering. When we looked at all the students enrolled in the course, we determined that almost $70 \%$ of our student population had not declared an engineering major, either because they were "Pre-Engineers" and were not yet accepted into the College of Engineering or because they were Open Option students. This significantly affected our course design, as we chose to tailor the content of the course to help the undeclared student population.

\section{COURSE DESIGN}

\begin{tabular}{|c|l|l|}
\hline Week & Topic & Objectives \\
\hline 1 & $\begin{array}{l}\text { Getting Oriented and } \\
\text { Involved }\end{array}$ & $\begin{array}{l}\text { Students will be able to navigate the engineering } \\
\text { center \& students will be able to identify at least one } \\
\text { extracurricular activity of interest }\end{array}$ \\
\hline 2 & The Disciplines & Students will be able to select a possible major \\
\hline 3 & The College Midterm & $\begin{array}{l}\text { Students will be able to identify resources to support } \\
\text { engineering success at CU }\end{array}$ \\
\hline 4 & Preparing for Careers & $\begin{array}{l}\text { Students will be able to compose a resume that will } \\
\text { prepare them for internships and job opportunities }\end{array}$ \\
\hline 5 & Midterm Week & No assignments. Good luck on midterms! \\
\hline 6 & Applying the Disciplines & $\begin{array}{l}\text { Students will be able to choose at least one } \\
\text { supercurricular opportunity of interest in engineering }\end{array}$ \\
\hline 7 & Considering Careers & $\begin{array}{l}\text { Students will be able to associate overcoming } \\
\text { challenge with the path toward professional success }\end{array}$ \\
\hline 8 & Integrity in Engineering & $\begin{array}{l}\text { Students will be able to apply ethics to the field of } \\
\text { engineering as a student and will understand the } \\
\text { importance of ethics in professional engineering }\end{array}$ \\
\hline 9 & Midterm Week & No assignments. Good luck on midterms! \\
\hline 10 & $\begin{array}{l}\text { Implementing your } \\
\text { Engineering Plan }\end{array}$ & $\begin{array}{l}\text { Students will be able to construct a professional goal } \\
\text { and an educational goal }\end{array}$ \\
\hline 11 & Complete your Final Project \\
\hline $12-16$ & This class has ended. Good luck with your other courses! \\
\hline
\end{tabular}

Table 1: Course Schedule

The design of the course was based on content pulled from previous iterations of this course in past years, as well as best practices learned from the introduction to engineering courses at other 
institutions (Brake 2016, Peuker 2016, ASEE 2017). The coursework was divided into two types of assignments: weekly homework and a final report. The course schedule is presented in Table 1.

At our university, semesters are 16 weeks long, usually lasting from mid-August to early-December, but we designed our course to only take 10 weeks, allowing the class finish before Fall/Thanksgiving break. Because our content was delivered primarily online (and not in a classroom), we chose to skip content on weeks where students had midterms and to end the course before Thanksgiving; this choice was made to maximize success for first-year students who often report high stress levels around midterms and finals (Seymour 1997, Weidner 1996). The ability to skip midterm weeks and to end the course early was also important for our assessment strategy since they gave the grading staff a buffer for grading and allowed us to schedule the grade-a-thon.

We managed all assignments and communication through the course's online LMS. Every week the students' would see a new weekly table that contained three activities named "Attend", "View", and "Read", and two homework assignments named "Do" and "Write". The Attend, View, and Read activities disseminated the course content through in-person events, online videos, and textbook reading. The Do assignments were as a quiz or survey that had students answer questions about the weekly activities and reflect on their immediate applicability. The Write assignments were one-page essays where we asked students to reflect on the weekly activities and to create a personal plan that would set themselves up to "Become a Successful Engineering Student". Students only received credit for the Do and Write assignments. The full assignment schedule is attached in the Appendix.

The final report was based on Steffen Peuker and Raymond B. Landis" "Design Your Process of Becoming a World-Class Engineering Student" curriculum (Landis 2013, Peuker 2016). This report was a compilation of the students' previous writing assignments and newly written introduction and conclusion sections. We gave the students the final project outline as well as a reference table that showed the corresponding weekly assignment for each section (see Appendix). This structure was copied from the Peuker and Landis curriculum and we presented this unique final project format to our students as a way to reinforce long-term goals ("Become a Successful Engineering Student”) and let them revisit their old work.

\section{ASSESSMENT}

Out instructional staff consisted of one Professor, one graduate lead Teaching Assistant (TA), and two undergraduate TAs. We also hired 16 temporary hourly graders near the end of the course. We implemented two grading strategies for the course assignments:

"Divide-and-Conquer" for weekly homework and a "Grade-a-thon" for the final report. Our assessment plan was heavily influenced by our course goals. This course was intended to be an introduction to our College of Engineering and engineering as a profession. Many of the assignments had our students reflecting on their personal goals, academic plans, and career ambitions, creating their own personalized plan for success. Since it was impossible to compare the content of the assignments from one student to another student, we graded based on honest 
effort, persistence, and growth over the course. This grading system is shown in our two grading strategies, which we detail below.

\section{A. Divide-and-Conquer}

Every week students had two homework assignments they had to complete: 1) one survey or quiz and 2) one writing assignment. The quiz or survey was automatically graded by the LMS. Quiz items were graded by correctness and survey items were graded on the length of response. Students were able to immediately see their grades after they took a quiz and to see which questions were marked incorrectly. We also allowed for unlimited quiz retakes, so if a student didn't get full credit the first time, they could retake the quiz for full credit. This allowed students to take full responsibility for their grade: if they wanted to put in the time and effort to retake the quiz, their grade could increase.. We wanted to allow for retakes to incentivize students to increase their grade and to give them a chance to learn from their incorrect answers and receive credit for correcting them.

The weekly written assignments were graded by the three TAs. The TAs split the students into three sections by last name (A-F, G-O, P-Z), each TA was responsible for one section and performed a combination of "hand-grading" and "mass-grading".

Hand-grading involved reading each student's writing assignment, assessing the work based on a rubric, writing comments to the students, and assigning a grade. Each week the lead TA would grade a few student assignments early and create a benchmark and grading rubric for that week. The undergraduate TAs would use that rubric to calibrate their grading so all TAs would grade the weekly assignments in an equitable fashion.

Mass-grading consisted of giving all students full credit for the assignment. Every week the TAs would hand-grade between 80-100 assignments and mass-grade the remaining 130-150 assignments. The TAs would leave feedback on every hand-graded assignment, differentiating it from a mass-graded assignment. The students with feedback would be able to tell their assignment was hand-graded and the students with no feedback, but a 100\% grade would know they had received full credit as a participation-type grade. This strategy had four main benefits to it:

\section{Selection}

The TAs would change which students were selected for hand-grading every week, so no student went more than two weeks without being hand-graded. This strategy allowed the three TAs to give select students meaningful feedback on their assignments and monitor student progress. Though each student would not receive a comment or feedback on their work every time, this strategy allowed more detailed feedback to be given to select students every week.

\section{Timing}

After the first week of grading, the TAs became increasingly efficient at reading the students' written work and averaged 3-4 minutes per assignment, which averaged to 4-6 hours per week 
spent on grading. Our TAs were hired for 10 hours a week, so this amount of grading was achievable for their availability.

\section{Common Feedback}

Hand-grading the assignments also allowed to accumulate common feedback comments and re-use those responses for multiple students. After grading the first few assignments, we would see common themes in the student assignments and use those the comments we left on those assignments on future student's assignments. For example, during "Week 6: Applying the Disciplines" the writing prompt was: "What is (at least) one opportunity in engineering, whether a minor, study abroad, research experience, or internship, that you plan to pursue? Why? When will you pursue this?" We noticed that a large number of students talked about obtaining an internship and studying abroad in their responses. We recorded the feedback we gave to the first 10-15 students and saw that the individual feedback responses sounded very similar to each other. So, we re-wrote these responses as six separate comments - three for each type of extracurricular activity, internships and studying abroad - that addressed a different issue the students brought up in their assignments. Table 2 shows these six responses.

\begin{tabular}{|c|c|}
\hline Study Abroad Comments & Internship Comments \\
\hline $\begin{array}{l}\text { Studying abroad is a great experience! } \\
\text { Planning your class schedule requires you } \\
\text { to plan a few years ahead, it's great that } \\
\text { you're thinking about it and looking into } \\
\text { it now! } \\
\text { Studying abroad is a great experience! } \\
\text { It's great to see that you know someone } \\
\text { who has studied abroad before. Use them } \\
\text { as a resource when you're applying and } \\
\text { planning for your semester abroad. }\end{array}$ & $\begin{array}{l}\text { Internships are great! Apply to as many as } \\
\text { possible, many of the large companies you } \\
\text { listed are incredibly competitive. Keep in mind } \\
\text { the local companies that are also looking for } \\
\text { interns, as they can be less competitive and } \\
\text { easier to be accepted. You will still get a great } \\
\text { experience working at a company (especially } \\
\text { since it is a smaller company and you can meet } \\
\text { more people and get to know the different } \\
\text { software positions better and in more detail). } \\
\text { Internships are great! Apply to as many as } \\
\text { possible, even if it's not exactly what you want } \\
\text { to do, it will still help you build your resume } \\
\text { and give you industry experience. There will } \\
\text { be more networking events and Spring } \\
\text { semester career fairs, so look out of them too. } \\
\text { Internships are great! Companies are almost } \\
\text { always looking for students who can program, } \\
\text { so you'll be in a great position to find an } \\
\text { internship. }\end{array}$ \\
\hline
\end{tabular}

Table 2: Common feedback comments left on Week 6's writing assignment 
Creating a list of common feedback comments allowed our grading team to address students who had similar questions or issues more efficiently since their feedback was copied directly from a list of pre-assembled comments. The students who brought up other issues in their assignments were given individual feedback that addressed their content of their homework more directly.

\section{Quality}

One of our concerns was that students would take advantage of the mass-grading and turn in poor quality work weekly. To combat this, the TAs would first hand-grade the assignments, so they could monitor the quality of student work. Every week, the TAs found that there was a consistent rate of $90-95 \%$ of students who turned in high-quality assignments, which followed the prompt and all requirements and earned the students full credit. Due to the overall consistent quality of student submissions, we reasoned that giving the remaining students full-credit in mass-grading would be an acceptable strategy since an overwhelming majority of submissions would have been assigned full credit if they had been hand-graded.

\section{B. Grade-a-thon}

The final type of assignment that required assessment was the final report. This report was an accumulation of the previous weekly assignments, where students were expected to create a cohesive strategy to "Become a Successful Engineering Student", as well as their resume, course plan, and newly written introduction and conclusion sections. These reports were 9-11 pages in length, not including appendices. Since this assignment was significantly longer than the one-page weekly assignments and required that every student be hand-graded, we created a "Grade-a-thon" event where we attempted to grade all of the student reports in 8 hours.

The grade-a-thon structure was created by augmenting grading practices implemented by the College Board for grading their Advanced Placement Exams (College Board 2017). Advanced Placement (AP) Exams are graded by using a combination of computer automation and hand-grading. AP exams that have written components are graded during a two-week period by select AP teachers in all-day grading events. The grade-a-thon used a similar structure: we required all graders to be present for the event, had a brief calibration session to standardize the grading, and attempted to grade all the reports in a single grading period.

The final reports were due on Sunday night, and we scheduled the grade-a-thon on the following Saturday. This gave us one week to make sure that all students had turned in their reports and resolve any submission discrepancies. The intention was also to host the grade-a-thon as soon as possible so that the instructional staff could process the class' grades quickly and students could receive their grades before the end of the semester.

\section{Hiring Additional Graders}

We estimated that the grade-a-thon event would require an additional 20 graders, with each grader taking 10 minutes per report. We paid each grader $\$ 100$ for the entire day, a rate of $\$ 12.50$ per hour. To advertise this opportunity, we hung posters around the College of Engineering and emailed departmental advisers. We had all interested parties fill out a short application that asked for basic information and required them to answer these three questions: 
1. Please list any classes you've worked as a TA or LA.

2. In 1 paragraph, describe your experience evaluating student work.

3. In 1 paragraph, describe your interest in supporting our grade-a-thon.

We rated each response on a scale $0-3$, with 3 being the best quality answer and 0 being a poor answer. If an applicant received a total score of 7-9, we offered a grading position to them. From the remaining applicants who scored 6s, we determined who was hired based on their short responses. We offered the grading position to 24 graduate students, expecting some to drop out before the event, a hypothesis that came true. However, in hindsight, we should have estimated a higher drop out ratio, since we had a large number of withdrawing the week before the grade-a-thon, leaving us with only 16 graders for the event.

\section{Structure of the Grade-a-thon}

The grade-a-thon was hosted on a Saturday from 9-5 in a large conference room on our research campus. Since this was a long event, we wanted to provide a pleasant and cheerful environment for all the graders, so we could avoid burn-out and keep everyone engaged. We choose a conference room that was especially large, so it could easily host $20+$ people; it was also a corner room with huge windows, lots of sunlight and great views of natural scenery, creating a calm and welcoming environment. We also provided breakfast and catered lunch for the graders, as an incentive and so that none of the graders had to go out for food. Table 3 shows the full schedule for the grade-a-thon.

\begin{tabular}{|r|l|}
\hline \multicolumn{2}{|c|}{ Grade-a-thon Schedule } \\
\hline $9: 00$ & Introductions \\
$9: 15$ & Grading calibration \\
$10: 30$ & Distribute student assignments and begin grading \\
$12: 30$ & Lunch and grading discussion \\
$1: 00$ & Round 2 of grading \\
$3: 00$ & Snack and grading discussion \\
$3: 30$ & Round 3 of grading \\
$5: 00$ & End \\
\hline
\end{tabular}

Table 3: Full Schedule for the grade-a-thon

We also included regularly scheduled breaks during the grade-a-thon the graders could take a break from grading and talk about the reports. These discussion sessions became a crucial aspect to the grade-a-thon since it provided a forum in which the graders could compare notes and perform mini-calibrations. It was also a great chance for all the graders to discuss grading tactics and talk about stand-out papers. The lead graduate TA was also able to answer questions and clarify any questions regarding the grading rubric. 


\section{Calibration}

The most important aspect of the grade-a-thon was the calibration session at the beginning of the event. Before the grade-a-thon, the lead graduate TA selected four reports that displayed a range of effort and ability. The TA pre-graded the reports with the same grading strategy used in the weekly grading assignments. During the grade-a-thon, the instructional staff first explained the rubric, shown in Table 4, and distributed the four example reports. We gave the graders 10 minutes to grade the first report; we told them we expected them to read the report, assign a grade based on the rubric, and give feedback. We timed this session publicly so the graders would get the chance to feel how long these tasks would take. Many of the graders were not finished reading the report by the end of the 10 minutes and had not even started on assessment yet. We waited for the graders to finish reading and assessing the report before moving on to the next step.

\begin{tabular}{|c|c|c|c|c|}
\hline Category & $4 p t s$ & 3pts & 2pts & 0pts \\
\hline Content & $\begin{array}{l}\text { All prompts as } \\
\text { outlined on the } \\
\text { project are } \\
\text { addressed } \\
\text { sufficiently }\end{array}$ & $\begin{array}{l}\text { Two or less } \\
\text { prompts are not } \\
\text { sufficiently } \\
\text { addressed }\end{array}$ & $\begin{array}{l}\text { Four or less } \\
\text { prompts are not } \\
\text { sufficiently } \\
\text { addressed }\end{array}$ & $\begin{array}{l}\text { Less than } 6 \\
\text { prompts are } \\
\text { sufficiently } \\
\text { addressed }\end{array}$ \\
\hline Fluency & $\begin{array}{l}\text { Each sentence is } \\
\text { clear and has } \\
\text { obvious emphasis. } \\
\text { All sound natural } \\
\text { when read aloud }\end{array}$ & $\begin{array}{l}\text { Some sentences } \\
\text { are awkward or } \\
\text { difficult to } \\
\text { understand; } \\
\text { almost all sound } \\
\text { natural when read } \\
\text { aloud }\end{array}$ & $\begin{array}{l}\text { Several sentences } \\
\text { are awkward or } \\
\text { difficult to } \\
\text { understand; most } \\
\text { sound natural } \\
\text { when read aloud }\end{array}$ & $\begin{array}{l}\text { Almost all } \\
\text { sentences are } \\
\text { awkward, } \\
\text { repetitive, or } \\
\text { difficult to } \\
\text { understand }\end{array}$ \\
\hline $\begin{array}{c}\text { Grammar and } \\
\text { Spelling }\end{array}$ & $\begin{array}{l}\text { Less than } 2 \text { spelling } \\
\text { or grammar } \\
\text { mistakes per page }\end{array}$ & $\begin{array}{l}\text { Less than } 4 \\
\text { spelling or } \\
\text { grammar } \\
\text { mistakes per page }\end{array}$ & $\begin{array}{l}\text { Less than } 6 \\
\text { spelling or } \\
\text { grammar } \\
\text { mistakes per page }\end{array}$ & $\begin{array}{l}\text { More than } 6 \\
\text { spelling or } \\
\text { grammar } \\
\text { mistakes per page }\end{array}$ \\
\hline Length & $\begin{array}{l}\text { Meets or exceeds } \\
\text { the stated length } \\
\text { requirement }\end{array}$ & 1 page short & 2 pages short & Less than 6 pages \\
\hline $\begin{array}{c}\text { Formatting } \\
\quad \text { and } \\
\text { Organization }\end{array}$ & $\begin{array}{l}\text { Adheres to all } \\
\text { formatting } \\
\text { requirements, has } \\
\text { clear organization, } \\
\text { and follows outline }\end{array}$ & $\begin{array}{l}\text { Adheres mostly } \\
\text { to all format } \\
\text { requirements, } \\
\text { mostly follows } \\
\text { outline }\end{array}$ & $\begin{array}{l}\text { Has major } \\
\text { formatting issues } \\
\text { and/or major } \\
\text { organizational } \\
\text { deficits }\end{array}$ & $\begin{array}{l}\text { Does not adhere } \\
\text { to format } \\
\text { requirements and } \\
\text { does not show } \\
\text { any organization }\end{array}$ \\
\hline
\end{tabular}

Table 4: Grading Rubric for the Final Report

After the graders were finished with the first report, we discussed each section of the rubric in length and what grade the student should receive for each section. This discussion took longer 
than anticipated, as many graders disagreed on what grade the students should receive. We then distributed the second example report and asked the graders to assess it. This report took the graders a shorter amount of time to grade, as they had adjusted to the 10 minute grading period quickly. There was still much discussion about the grade the student should have received for the report. The graders also found it difficult to compare the two reports with each other, since one student wrote with a high English fluency and the other was an international, English-language learner student. After much discussion, each grader decided on a grade for the two students, grading within a 5\% margin. We found this margin an acceptable difference in range for the graders. We initially thought we could calibrate all four student reports, but the discussion about the two students took longer than anticipated, and we could only calibrate to two students.

IV. Grading

All graders were given "grader" permissions to the LMS where they could access all student reports. They were able to read the reports and immediately give feedback and a grade all digitally through the LMS. During the grade-a-thon, many graders discovered common mistakes that students would include in their reports, for example, not including the appendices or not formatting the guidelines. The lead graduate TA created rules for these common mistakes that automatically deducted points from the rubric. These rules were written on a large whiteboard in the conference room for all the graders to see. These also created a set of standards that helped the graders further calibrate to one another.

\section{Round Two of Grading}

At the end of the eight-hour grade-a-thon, the graders had only completed grading approximately $70 \%$ of the total reports. The graders graded $17-22$ reports each, with an average of 22 reports per grader (3.8 standard deviations), which meant that each grader averaged 16 minutes per report. We were also short-staffed during the grade-a-thon since we had four graders withdraw from the grade-a-thon in the in the last week (only 16 of the anticipated 20 were available).

To complete the grading, we re-hired four of the graders for another round of grading, paying them an additional $\$ 100$ each. The TAs also helped with the second round of grading. The remaining reports were completed within the week after the grade-a-thon. This meant that students received their graded final reports within two weeks or turning them in and were still able to receive their course grade before the end of the semester, which was a goal of ours.

\section{Benefits}

The grade-a-thon strategy allowed all students to receive individual assessment and feedback, while simultaneously expediting grading time and at a relatively low financial cost to the university. Hiring temporary graders for one assignment allowed us to quickly calibrate to that assignment and grade hundreds of reports at a time. The grade-a-thon event gave an opportunity for all the graders to meet in one place and allowed the instructional staff the time to explain the rubric and give grading standards to everyone in a central time and place. 


\section{CONCLUSION}

We developed the Divide-and-Conquer and Grade-a-thon strategies as alternatives to full automated assessment or hiring full-time appointment-based TAs. The Divide-and-Conquer grading strategy allowed us to grade weekly written assignments and give comments and feedback to the students. Since we only graded a portion of the students each week, we were able to divide the students into manageable and gradable sections and evaluate each student individually. The grade-a-thon strategy allowed us to calibrate 16 graders at once and achieve standardized grading practices. Each grader was able to spend a sufficient amount of time on each student's report and give them individualized feedback. We were able to grade all 700 student reports within two 8 hour grading periods. Our experiences with this introduction to engineering course show us that we can achieve effective assessment for a large enrollment course with a relatively small instructional staff.

\section{APPENDIX}

\section{A. Full Course Assignment Schedule}

\section{Week 1, [Date]}

Getting Oriented and Involved

Objectives: Students will be able to navigate the engineering center \& students will be able to identify at least one extracurricular activity of interest

\begin{tabular}{|c|c|}
\hline Attend & - [Welcome Fair - Student Clubs and Campus Resources] \\
\hline View & $\begin{array}{l}\text { - [All videos in the Getting Oriented Playlist - videos introducing the course } \\
\text { and the college to students] } \\
\quad \text { [Introduction to the course] } \\
\circ \text { Moonshot (3:45): } \\
\quad \frac{\text { https://www.youtube.com/watch?v=0uaquGZKx } 0}{\text { [Navigating the College of Engineering Building] }}\end{array}$ \\
\hline Read & $\begin{array}{l}\text { - Landis, Section 7.1: Participation in Student Organizations (7 pages) } \\
\text { - [Explore list of student clubs, organizations, and societies] }\end{array}$ \\
\hline Do & $\begin{array}{ll}\text { - } & \text { [Pre-Course Feedback Survey] (6 questions, } \sim 3 \text { minutes) } \\
\text { - } & \text { [Syllabus Quiz] }\end{array}$ \\
\hline Write & $\begin{array}{l}\text {-Write: Extracurricular opportunities } \\
\circ \text { Name two extracurricular opportunities of interest to you. Why do } \\
\text { they appeal? Describe your plan for joining or becoming involved } \\
\text { with at least one of these. } \\
\circ 500-600 \text { words (1 page) }\end{array}$ \\
\hline
\end{tabular}

${ }^{1}$ Any items written in square brackets, such as: [item], are specific to our university or this course. When applicable, we have given the name of the item's and a general description of it. 


\begin{tabular}{|c|c|}
\hline \multicolumn{2}{|c|}{$\begin{array}{c}\text { Week 2, [Date] } \\
\text { The Disciplines } \\
\text { Aerospace Engineering Student Group: } \\
\text { Objective: Students will be able to confirm Aerospace Engineering as their major } \\
\text { Pre-Engineering and Other Engineering Student Groups: } \\
\text { Objective: Students will be able to select a possible major }\end{array}$} \\
\hline Attend & - [Faculty Panel] \\
\hline View & $\begin{array}{l}\text { - } \text {-As many of Major videos as you want! (Minimum of 3.) Select from } 11 \\
\text { videos in the Major Video Playlist: - These videos have descriptions of all } \\
\text { the College of Engineering majors.] }\end{array}$ \\
\hline Read & $\begin{array}{l}\text { - Landis, Section 2.1: What is Engineering ( } 3 \text { pages) } \\
\text { - Landis, Appendix E: Description of Engineering Disciplines ( } 20 \text { pages) } \\
\text { - } \quad \text { College of Engineering Abbreviation cheat sheet] }\end{array}$ \\
\hline Do & - [Quiz: Abbreviation and Major Videos] \\
\hline Write & $\begin{array}{l}\text { - Course Planning } \\
\circ \text { Select a major and chart out your courses through graduation. } \\
\text { [Read attached assignment for more details.] } \\
\circ \quad \text { [Use one of the two following file templates when planning your } \\
\text { courses] }\end{array}$ \\
\hline
\end{tabular}

\section{Week 3, [Date] \\ The College Midterm}

Objective: Students will be able to identify resources to support engineering success at [Our University]

\begin{tabular}{|c|c|}
\hline Attend & $\begin{array}{l}\text { - [Math exam preparation activities! (Office hours, math help room, practice } \\
\text { exams, oral exams.) Read attached assignment for more details] }\end{array}$ \\
\hline View & $\begin{array}{ll}\text { - [All videos from the College Midterm Playlist: }] \\
\therefore & {[\text { Why the university gives exams }]} \\
\circ & {[\text { What I wish I had known before my first midterm }]} \\
\circ & {[\text { Strategies for Success on midterms }]}\end{array}$ \\
\hline Read & $\begin{array}{ll}\text { - } & \text { [Library Resource Guide] } \\
\text { - } & {[\text { Student Resource Guide] }} \\
\text { - } & {[\text { Engineering Academic Support Guide }]} \\
\text { - } & {[\text { Academic Support for Pre-Engineering students }]}\end{array}$ \\
\hline Do & $\begin{array}{l}\text { - [Survey: Math Exam Preparation] } \\
\quad \text { [This survey will be about the math preparation you did this week. } \\
\text { Do not take this quiz until you have completed the "Attend" } \\
\text { assignment for this week.] }\end{array}$ \\
\hline Write & $\begin{array}{l}\text { - Write: Resources available to you } \\
\text { "Being a good student does not mean being independent." One } \\
\text { common theme among successful students in our college is that } \\
\text { they seek help. } \\
\text { Describe three resources you will use when you are seeking help in } \\
\text { your courses. Have you used any of these yet? Set yourself a goal } \\
\text { as to when and how often you will use each of these available } \\
\text { resources. } \\
\circ 500-600 \text { words (1 page) }\end{array}$ \\
\hline
\end{tabular}

\section{Week 4, [Date]}




\begin{tabular}{|c|c|}
\hline \multicolumn{2}{|c|}{$\begin{array}{c}\text { Preparing for Careers } \\
\text { Objective: Students will be able to compose a resume that will prepare them for internships and job } \\
\text { opportunities }\end{array}$} \\
\hline Attend & $\begin{array}{l}\text { - } \quad \text { Alumni Panel] } \\
\circ \quad \text { [If you attend in person, you will be able to ask questions and may } \\
\text { leave with a token of attendance. If you don't attend in person, you } \\
\text { should watch the recording afterwards.] }\end{array}$ \\
\hline View & $\begin{array}{l}\text { - [Career Services - video describing how campus career services works and } \\
\text { how students can use it as a resource] }\end{array}$ \\
\hline Read & $\begin{array}{l}\text { - Landis, Section 2.4: Rewards and Opportunities of an Engineering Career } \\
\text { (11 pages) } \\
\text { - Landis, Section 2.7: Engineering Job Functions (4 pages) } \\
\text { - } \quad \text { Resume Checklist - list of things that should be included on a resume as } \\
\text { well as tips for formatting and design] } \\
\text { - [Sample Resume] }\end{array}$ \\
\hline Do & $\begin{array}{l}\text { - [Mid-Course Feedback Survey] (10 questions, } ~ 5 \text { minutes) } \\
\text { - Create your Engineering Resume } \\
\text { Create a resume that adheres to the "Resume Checklist" } \\
\text { guidelines. Look at the "Sample Resume" to help with what your } \\
\text { resume should look like } \\
\text { Details } \\
\text { - Maximum } 1 \text { page. Do not go onto a second page } \\
\text { - Turn in assignment in a standard file type, docx or pdf } \\
\text { This Resume assignment will replace the Do quiz for this } \\
\text { week }\end{array}$ \\
\hline Write & $\begin{array}{l}\text { Write: Additional items on your resume } \\
\text { What is one item you wish you could list on your resume? What is } \\
\text { your plan for seeking and securing that opportunity? That is, when } \\
\text { do you hope to participate in this opportunity? How and when will } \\
\text { you apply or prepare to do so? } \\
\circ 500-600 \text { words (1 page) }\end{array}$ \\
\hline
\end{tabular}

\begin{tabular}{|c|c|}
\hline \multicolumn{1}{|c|}{\begin{tabular}{c} 
Week 5, [date] \\
Midterm Week \\
\multicolumn{1}{|c|}{ No Assignments. Good Luck! }
\end{tabular}} \\
\hline $\begin{array}{c}\text { Optional Review of } \\
\text { your Resume }\end{array}$ & - $\begin{array}{c}\text { Resume Critique } \\
\circ \quad \text { [Drop-in resume critique being held on campus] } \\
\text { Drop in Career Center Hours } \\
\text { [Hours] }\end{array}$ \\
\hline
\end{tabular}

\section{Week 6, [Date]}

Applying the Disciplines

Objective: Students will be able to choose at least one supercurricular opportunity of interest in engineering

Attend

- [Opportunity Panel (study abroad, research, active learning, internship)]

- [If you attend in person, you will be able to ask questions and may leave with a token of attendance. If you don't attend in person, you should watch the recording afterwards.] 


\begin{tabular}{|c|c|}
\hline View & $\begin{array}{l}\text { - [As many of Minor videos as you want! (Minimum of 2). Select the videos } \\
\text { from the CEAS Minor Playlist - These videos describe the minors available } \\
\text { in the College of Engineering] }\end{array}$ \\
\hline Read & $\begin{array}{l}\text { - [Guide to Active Learning Opportunities - Guide developed by the College } \\
\text { of Engineering listing learning opportunities the college offers] }\end{array}$ \\
\hline Do & $\begin{array}{l}\text { - [Study Abroad } 101 \text { Quiz or Career Services portfolio] } \\
\circ \quad \text { [For more details about the assignment, read the attached } \\
\text { assignment] }\end{array}$ \\
\hline Write & $\begin{array}{l}\text { Just a reminder, you get out of this course what you put into it. These assignments } \\
\text { are not meant to be busy work, but to introduce you to different opportunities and } \\
\text { areas that can benefit you at [Our University]. Take advantage of these assignments } \\
\text { to explore these areas and create a plan for your time at [Our University]! All } \\
\text { assignments are building towards your plan to become a [Successful Engineering } \\
\text { Student]. } \\
\text { - Write: Opportunities in Engineering } \\
\text { o What is (at least) one opportunity in engineering, whether a minor, } \\
\text { study abroad, research experience, or internship, that you plan to } \\
\text { pursue? Why? When will you pursue this? } \\
\text { o } 500-600 \text { words (1 page) }\end{array}$ \\
\hline
\end{tabular}

\section{Week 7, [Date] \\ Considering Careers}

Objective: Students will be able to associate overcoming challenge with the path toward professional success

\begin{tabular}{|c|c|}
\hline Attend & $\begin{array}{l}\text { - [Career Services Career Fair] } \\
\circ \quad \begin{array}{l}\text { Bring your resume, and introduce yourself to at least three } \\
\text { organizations }\end{array} \\
\circ \quad \text { [Review the attached Tips Page for more information about } \\
\text { appropriate dress code and introduction scripts] }\end{array}$ \\
\hline View & $\begin{array}{l}\text { - [As many of Career videos as you want! (Minimum of 2). Select from the } 8 \\
\text { videos in the Careers as Engineers Video Playlist. - These videos } \\
\text { interviewed alumni and they discussed their careers and how they use their } \\
\text { engineering degrees at their jobs.] }\end{array}$ \\
\hline Do & $\begin{array}{l}\text { - Interview an engineer! Read the attached document for more details about } \\
\text { the assignment - Interview an upperclassperson, TA, professor, alumni, or } \\
\text { engineer about their experiences becoming an engineer, the challenges } \\
\text { they faced, and ask for any advice they would give a first-year engineer] } \\
\text { [Record and reflect on the interview in the Survey: What did you } \\
\text { learn from the interview?] }\end{array}$ \\
\hline Write & $\begin{array}{l}\text { Write: Your unique strengths } \\
\text { The path toward an engineering degree may have bumps. As you } \\
\text { heard from the professionals interviewed, it behooves you to be } \\
\text { prepared to deal with inevitable adversity. What unique strengths } \\
\text { do you bring to engineering? } \\
\text { For example: Do you speak more than one language? Are } \\
\text { you the first in your family to attend college? Do you come } \\
\text { from a large family? } \\
\text { How will you use this strength to be a better engineer? } \\
\text { - } 500-600 \text { words (1 page) }\end{array}$ \\
\hline
\end{tabular}




\begin{tabular}{|l} 
Week 8, [Date] \\
Integrity in Engineering \\
Objectives: Students will be able to apply ethics to the field of engineering as a student and will \\
understand the importance of ethics in professional engineering.
\end{tabular}

\begin{tabular}{|c|}
\hline Week 9, [Date] \\
Midterm Week \\
No Assignments. Good Luck! \\
\hline
\end{tabular}

\begin{tabular}{|c|c|}
\hline \multicolumn{2}{|c|}{$\begin{array}{c}\text { Week 10, [Date] } \\
\text { Implementing your Engineering Plan } \\
\text { Objective: Students will be able to construct a professional goal and an educational goal }\end{array}$} \\
\hline Attend & 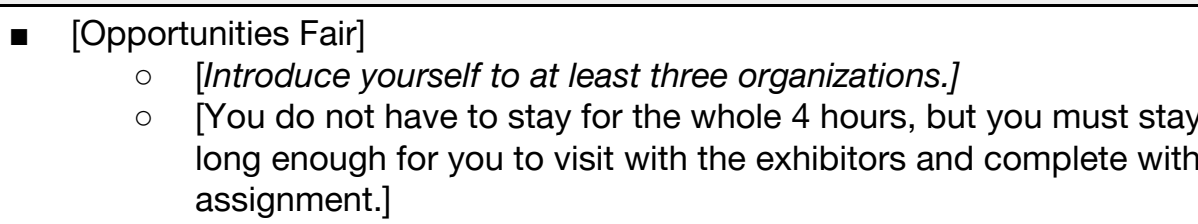 \\
\hline Do & $\begin{array}{ll}\text { - } & \text { [Survey: What did you learn from the Opportunities Fair?] } \\
\text { - } & \text { [Post-Course Feedback Survey] (10 questions, } \sim 6 \text { minutes) }\end{array}$ \\
\hline Write & Write: Your goals \\
\hline
\end{tabular}




\begin{tabular}{|c|c|}
\hline$\circ \begin{array}{l}\text { What is your goal for after graduating from [Our University]? What } \\
\text { do you think you want to do and why? To get there, what is your } \\
\text { goal for your educational path at [Our University]? In how many } \\
\text { years do you want to graduate? What GPA do you aspire to have? } \\
\circ \quad 700-900 \text { words (1-2 pages) }\end{array}$ \\
\hline
\end{tabular}

Weeks 11, 10/31

Complete your Final Project

Do

- [Final Project Assignment Description]

- [Template for the final project] 


\section{B. Final Project Outline}

1. Introduction

2. Goal Setting

a. Introduce yourself and tell us who you are. Explain why you are a [Our university] engineering student

a. Setting goals after graduation

b. Setting a road map to guide you over the next few years

3. Academic and Career Path

a. Participating in extracurricular activities

b. Identify resources to help you along your path

c. Focus on integrity in engineering

4. Personal Development
a. Your personal strengths
b. Identifying opportunities available to you
c. Future plans

5. Conclusion

a. What you need to do to move from where you are to where you will need to be to become a "Successful Engineering Student"?

6. Appendix

b. End with a quote that inspires you

a. Course Planning

b. Resume

\section{Final Project Outline with Corresponding Weekly Assignments}

\begin{tabular}{|l|l|}
\hline \multicolumn{1}{|c|}{ Final Project Outline } & \multicolumn{1}{c|}{ Corresponding Write and Do Assignment } \\
\hline $\begin{array}{l}\text { 1a. Introduce yourself and tell us who you are. } \\
\text { Explain why you are a [Our University] } \\
\text { engineering student }\end{array}$ & $\begin{array}{l}\text { NEW - Write an introduction to this report. This } \\
\text { should be about 200-300 words in length. }\end{array}$ \\
\hline 2a. Setting goals after graduation & Week 10 - Write: Your goals \\
\hline $\begin{array}{l}\text { 2b. Setting a road map to guide you over the } \\
\text { next few years }\end{array}$ & $\begin{array}{l}\text { Week 10 - Write: Your goals - You should also } \\
\text { reference Appendix A in this section }\end{array}$ \\
\hline 3a. Participating in extracurricular activities & Week 1 - Write: Extracurricular opportunities \\
\hline $\begin{array}{l}\text { 3b. Identify resources to help you along your } \\
\text { path }\end{array}$ & Week 3 - Write: Resources available to you \\
\hline 3c. Focus on integrity in engineering & Week 8 - Write: Ethics and careers \\
\hline 4a. Your personal strengths & Week 7 - Write: Your unique strengths \\
\hline 4b. Identifying opportunities available to you & Week 6 - Write: Opportunities in engineering \\
\hline 4c. Future plans & $\begin{array}{l}\text { Week 4 - Write: Additional items on your resume - } \\
\text { You should also reference Appendix B in this section }\end{array}$ \\
\hline $\begin{array}{l}\text { 5a. What you need to do to move from where } \\
\text { you are to where you will need to be to } \\
\text { become a "Successful Engineering Student"? }\end{array}$ & $\begin{array}{l}\text { NEW - Write a conclusion to this report. This should } \\
\text { be 200-300 words in length }\end{array}$ \\
\hline Appendix A: Course Planning & Week 2 - Course Planning \\
\hline Appendix B: Resume & Week 4 - Do: Resume \\
\hline
\end{tabular}




\section{REFERENCES}

ASEE. 2017. "Case Studies: American Society for Engineering Education.” Accessed January 20, 2017.

https://www.asee.org/engineering-enhanced-liberal-education-project/case-studies.

Brake, Nicholas Andres, and James C. Curry. "The Impact of One-Credit Introductory Engineering Courses on Engineering Self-Efficacy: Seminar v. Project-Based,” 2016.

College Board. 2017. "About AP Scores - The College Board.” Accessed January 20, 2017. https://apscore.collegeboard.org/scores/about-ap-scores//.

Essick, Ray, Matthew West, Mariana Silva, Geoffrey L. Herman, and Emma Mercier. "Scaling-up Collaborative Learning for Large Introductory Courses Using Active Learning Spaces, TA Training, and Computerized Team Management: American Society for Engineering Education.” In ASEE “16: ASEE”s 123th Annual Conference \& Exposition, 2016.

Landis, Raymond B. Studying Engineering: A Road Map to a Rewarding Career, 2013.

Peuker, Steffen, and Raymond B Landis. "Workshop: 'Design Your Process of Becoming a World-Class Engineering Student'- A Powerful Project for Enhancing Student Success.” In Proceedings from the 9th Annual First Year Engineering Experience (FYEE) Conference. Columbus, OH, USA, 2016.

Seymour, E., and N. M. Hewitt, Talking About Leaving: Why Undergraduates Leave the Sciences. Boulder, CO: Westview Press, 1997.

Weidner G., C. W. Kohlmann, E. Dotzauer, and L. R. Burns, "The effects of academic stress on health behaviors in young adults," Anxiety, Stress \& Coping, vol. 9, no. 2, pp. 123-133, 1996. 

